\title{
CD3D Gene
}

National Cancer Institute

\section{Source}

National Cancer Institute. CD3D Gene. NCI Thesaurus. Code C38898.

This gene is involved in immunity/defense via the activation of T cells. 